\title{
BADENIAN (MIDDLE MIOCENE) LAMINATED GYPSUM FACIES FROM KUDRYNTSI ON ZBRUCH RIVER (WEST UKRAINE)
}

T. M. Peryt' ${ }^{1}$, D. Peryt ${ }^{2}$, A. Poberezskyy ${ }^{3}$

\section{ФАЦІї ЛАМІНОВАНИХ БАДЕНСЬКИХ ГІПСІВ У КУДРИНЦЯХ НАД ЗБРУЧЕМ (ЗАХІДНА УКРАЇНА)}

\author{
Т. М. Перит ${ }^{1}$, Д. Перит ${ }^{2}$, А. Побережський ${ }^{3}$
}

Laminated gypsum was recorded in Kudryntsi on Zbruch River (West Ukraine) in the most marginal part of the Badenian evaporite basin above the series of stromatolitic gypsum and below the Ratyn Limestone. The gypsum lamination is rarely regularly planar, and erosional surfaces, wavy and lenticular lamination, isolated cross-laminated lenses of coarser-grained material as well as deformational structures: convolutions and in situ brecciation of lamina sets are quite frequent. The sets of planar laminae are commonly intercalated by sets showing deformations what indicates a syndepositional origin of the observed deformations which are interpreted to be caused by earthquakes related to the activation of faults which frame the Kolomyya graben. Keywords: laminated gypsum, Badenian, deformation structures, earthquakes.

У Кудринцях, розташованих у крайній периферійній частині баденського евапоритового басейну, вище строматолітових гіпсів, але нижче ратинських вапняків виявлено товщу ламінованих гіпсів. Ламінованість гіпсів рідко є рівномірною і її супроводжують ерозійні поверхні, хвиляста та лінзовидна ламінація, ізольовані скісноверствуваті більш грубозернисті лінзи поміж дрібнозернистих відкладів, а також деформаційні структури, утворені в результаті пластичного деформування та брекчіювання груп ламін (in situ). Групи горизонтально залягаючих ламін часто перешаровуються з групами, які проявляють деформаційні властивості, що вказує на седиментаційний генезис цих порушень, викликаних, правдоподібно, землетрусами, пов'язаними з активізацією розломів, що оточують Коломийську западину.

Ключові слова: ламіновані гіпси, баден, деформаційні структури, землетруси.

\section{ВСТУП}

Баденські гіпси Передкарпатського прогину утворилися в умовах саліни $[7,13,15]$, яку можна порівняти із сучасними аналогами $[10,12]$. Дослідження сульфатних відкладів у крайовій зоні платформи показали присутність трьох головних типів гіпсових розрізів [2, 3]. Кожен із цих типів є пов'язаний з іншою фаціальною зоною. У першій та другій зонах домінують автохтонні гіпси: у першій зоні, прилеглій до країв гіпсового басейну, строматолітовий гіпс, а у другій, розташованій в напрямку до центра басейну, строматолітовий гіпс у нижній частині та шаблевидний гіпс у верхній. У третій зоні автохтонні гіпси (в нижній частині скловидний гіпс, далі послідовно - строматолітовий, трав'янистий та шаблевидний) перекриті алохтонними (кластичними) гіпсами.

Кореляція цих зон можлива завдяки характерним шарам (marker beds), а також кореляційним поверхням $[3,16]$. Однією із таких важливих кореляційних поверхонь $€$ границя автохтонних та алохтонних гіпсів, яка відображає важливу зміну в історії басейну $[2,13]$ і через це трактується в основному як ізохронна.

Табл. 1. Дані ізотопічних аналізів вапняків

\begin{tabular}{|c|c|c|c|c|}
\hline $\begin{array}{c}\text { Рік відбору } \\
\text { зразка }\end{array}$ & Номер зразка & Локалізація зразка & $\begin{array}{c}\delta^{13} \mathrm{C} \\
{[\% \text { o }}\end{array}$ & $\begin{array}{c}\delta^{18} \mathrm{O} \\
{[\% \text { o] }}\end{array}$ \\
\hline 1994 & 7 & $\begin{array}{c}\text { верхня частина вапнякових } \\
\text { прошарків }\end{array}$ & $-10,17$ & 0,57 \\
\cline { 2 - 5 } & 8 & нижня частина & $-6,84$ & $-2,39$ \\
\cline { 2 - 5 } & 9 & на контакті & $-6,21$ & $-1,51$ \\
\hline \multirow{4}{*}{1997} & А1 & нижня частина (низ) & $-5,91$ & $-2,5$ \\
\cline { 2 - 5 } & А2 & нижня частина (верх) & $-6,25$ & $-2,56$ \\
\cline { 2 - 5 } & В1 & верхня частина (низ) & $-6,33$ & $-2,03$ \\
\cline { 2 - 5 } & В2 & верхня частина (верх) & $-7,93$ & $-2,38$ \\
\hline
\end{tabular}


На території східної частини Тернопільської області та прилеглої до неї західної частини Хмельницької області, а також північносхідного краю Чернівецької області (рис. 1) алохтонні гіпси зустрічаються дуже рідко. Їх присутність над автохтонними гіпсами підтверджена в Анадолах (там представлені ламіновані та кластичні пластові гіпси), в Устечку (ламіновані гіпси та гіпсові брекчії), у свердловині № 2, в 6 км на ЗПн3 від Веренчанки (ламіновані сульфати та сульфатні брекчії) та Ниври $[2,3,13,15,20]$. В останній час, у зв'язку із збільшенням фронту робіт по експлуатації гіпсів у діючому кар'єрі в Кудринцях, відкрилося раніше не відоме відслонення, вище строматолітових гіпсів - комплекс ламінованих гіпсів (рис. 2-4).

\section{РОЗРІЗ ГІПСІВ У КУДРИНЦЯХ}

Баденські гіпси у Кудринцях залягають вище дрібнозернистих пісковиків сеноману, які відслонюються у лівому борті долини р.Збруч, на північ від кар'єру. Вище залягає товща строматолітових гіпсів і гіпсових мікробіалітів потужністю біля 14 м (рис. 2) [2]. Ïx інтерпретують як мілководні відклади типу majanna (одиниця $\mathrm{M}$ за [5]). У верхній частині строматолітових гіпсів, приблизно 2,5 м нижче покрівлі цієї одиниці, на розмитій поверхні виявлено перешаровування (потужністю до 20 см) мікрозернистих вапняків типу mudstone i wackestone 3 морською фауною (планктонні форамініфери, птероподи, остракоди і вапняний нанопланктон) [15]. Ізотопні дослідження (к-сть аналізів - 7) проведені доктором Т. Дуракевічем у лабораторії масспектрометрії Інституту фізики М. Склодовської-Кюрі в Любліні, дали такі величини для $\delta^{13}$ С: від -5,9 \%о до -10,2 \%о (середнє: $-7,1 \%$ ), а для $\delta^{18}$ О: від 0,6 \%о до $-2,6 \%$ (середнє: $-1,8 \%$ \%) (табл. 1):

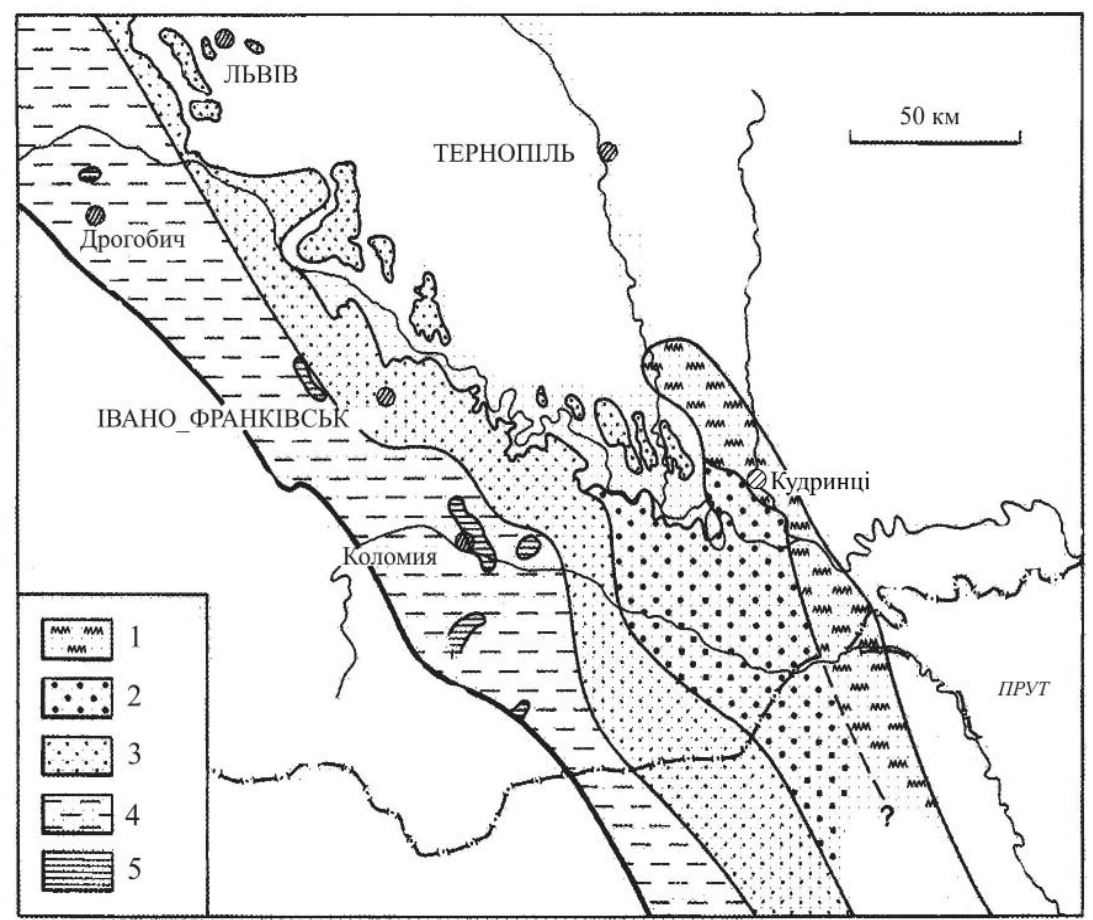

Рис. 1. Розташування кар'єру гіпсів у Кудринцях на основі карти фаціальних зон баденських гіпсів [3]

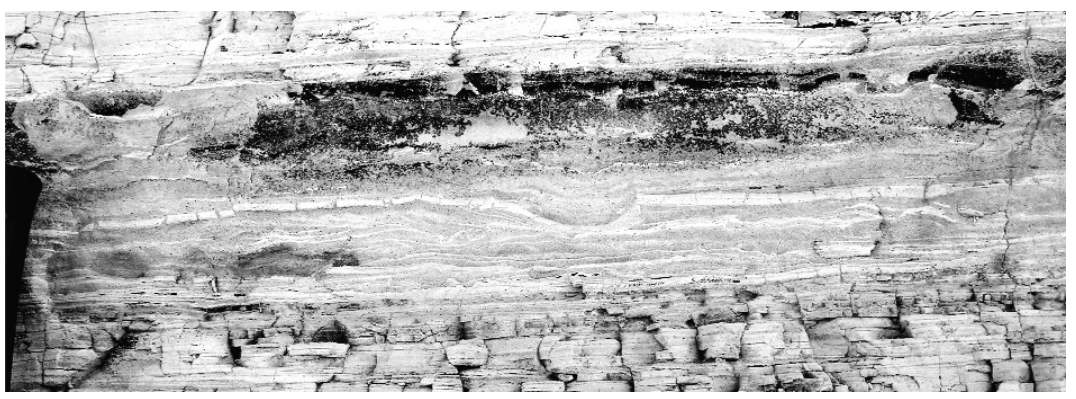

Рис. 2 a. Пакет гіпсу з деформованою, нерівномірною ламінацією і тріщинуватими ламінами. Ширина об'єкту представленого на фото складає 39 см

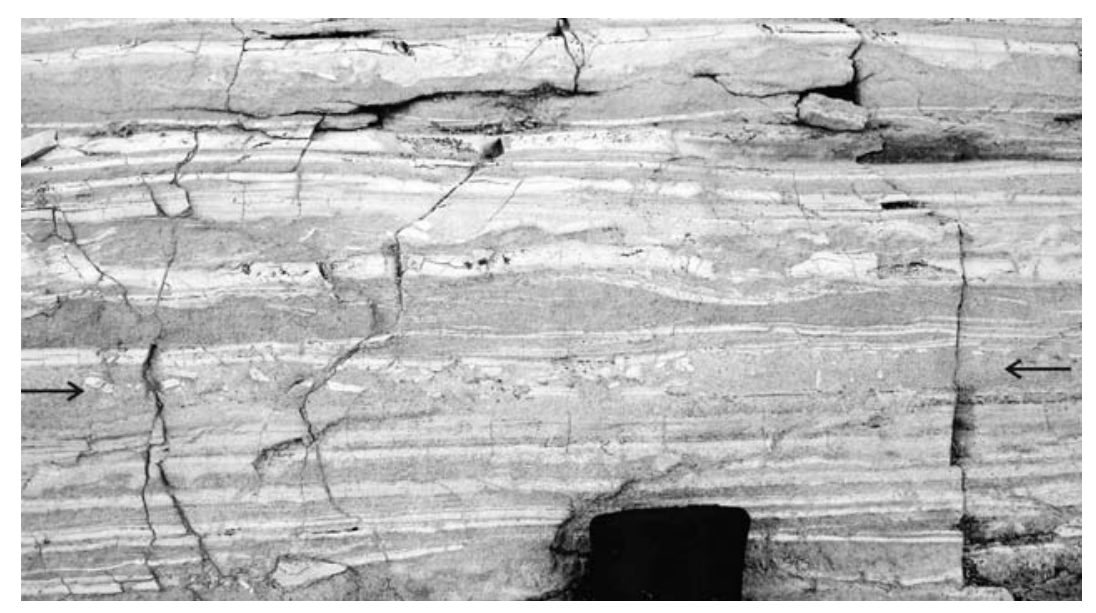

Рис. 2 б. Пакет гіпсу з нерівномірною ламінацією; деякі ламіни (наприклад, ламіна позначена стрілками) вміщують дрібні уламки гіпсу. Ручка молотка має ширину 3,7 см 
Вище строматолітових гіпсів залягають ламіновані гіпси; контакт цих двох одиниць не відслонюється. Потужність комплексу ламінованих гіпсів становить біля 4 м, вони перекриті перекристалізованими гіпсами (потужністю до $1 \mathrm{~m}$ ). На гіпсах залягають глини потужністю 10 - 30 см, перекриті ратинськими вапняками потужністю до 9 см [1]. Над ратинськими вапняками залягають мергелі, які в інтервалі 4 м вище ратинських вапняків містять прошарки вапняків і пісковиків потужністю до $15 \mathrm{~cm}$. Варто зауважити, що у ламінованих гіпсах зустрічаються ламіни тонковолокнистого різновиду (satin spar) (рис. 3 a, б), найчастіше вони залягають горизонтально. У відслоненнях недалеко від замку, часто спостерігаються вторинні жовнові гіпси. Також жовнові та тонковолокнисті гіпси спостерігаються локально у природних відслоненнях на північ від кар'єру в обривах по лівій стороні Збруча.

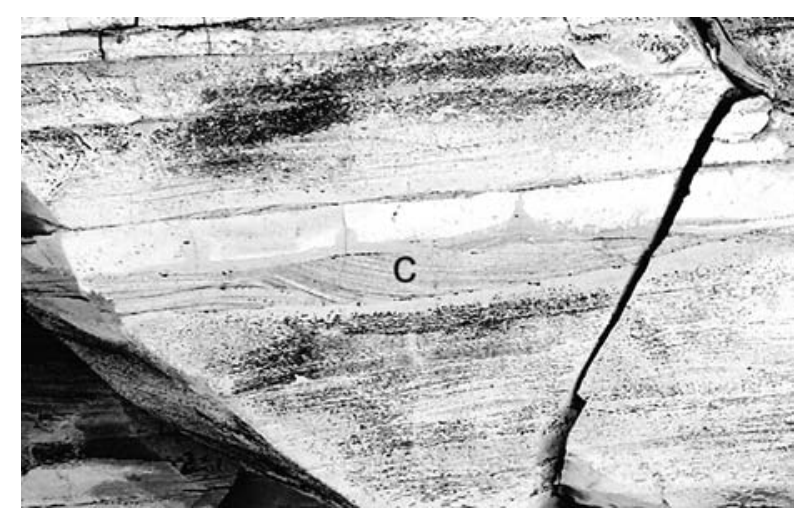

Рис. 2 в. Лінзовидна ламінація (у складі домінує кальцит - с) в межах ламінованих гіпсів з прошарками масивних гіпсів (на фото над лінзою вапняку). Об'єкт представлений на фото має ширину 19 см

\section{ОПИС ЛАМІНОВАНИХ ГІПСІВ}

Ламіновані гіпси складені ламінамі товщиною менше ніж 1 мм (рис. 3 а). Ламінованість рідко є рівномірною, її супроводжують такі порушення як дрібні заглибини і ерозійні поверхні (рис. 2 a, б), хвиляста та лінзовидна ламінація, а також ізольовані скісноламіновані лінзи більш грубозернисті поміж дрібнозернистих відкладів (рис. 2 в). Місцями ці порушення ламінації супроводжуються пластичною деформацією і брекчіюванням груп ламін (рис. 4 a, б). Хоча вони не пов'язані з певними частинами
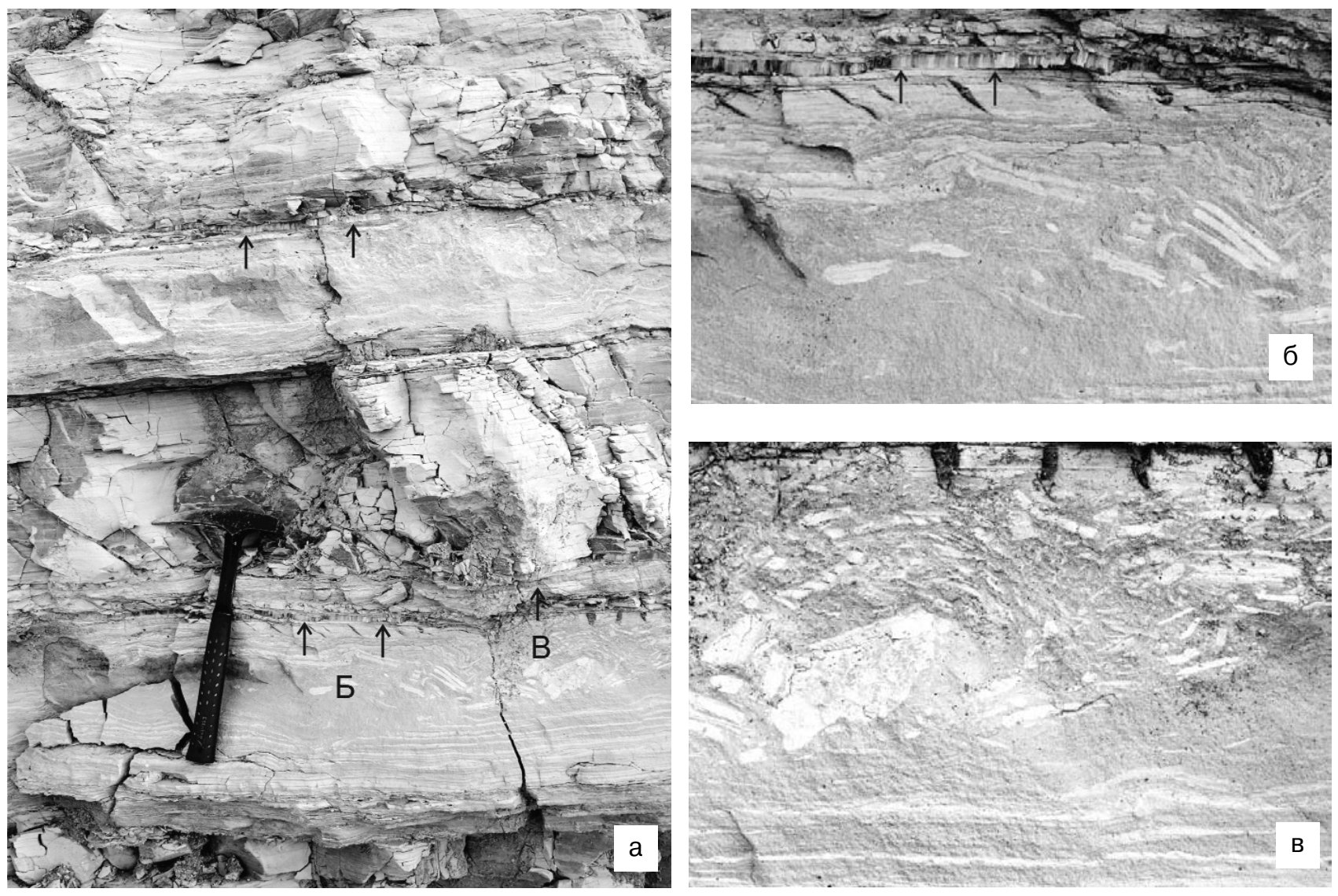

Рис. 3. Перешаровування гіпсу з рівномірно і горизонтально залягаючими ламінами та масивного гіпсу, який містить реліктові деформації ламін і уламки гіпсу, а також ламіни тонковолокнистого гіпсу (satin spar; показано стрілками): а - загальний вигляд і розташування фото б та в; б, в - фрагменти фото а. Молоток на фото а має довжину 32,7 см 
стратиграфічного розрізу, але особливо інтенсивно виражені на рівні 2 та 1,4 м нижче покрівлі гіпсів, а рівень у якому спостерігаються порушення виразно проявляється в розрізі. Ламінований гіпс буває перетворений на брекчію, і у цьому випадку перехід до брекчії часто є поступовим (рис. 4, а); брекчіювання часто спостерігається на рівнях де відмічені деформації. Варто згадати, що часто у відслоненнях $€$ брекчії пов'язані з карстом (або ж із палеокарстом), але синседиментаційна ґенеза описаних брекчій не викликає сумніву, беручи до уваги іх стратифіковане залягання.

Групи горизонтально залягаючих ламін часто перешаровуються з групами ламін, що зім'яті у складки, часом складчастість інтенсивна. Досить частими є дрібні скиди, тоді вони відірвані від материнської основи. Ламіновані гіпси перешаровуються з грубозернистим гіпсом, найвірогідніше, кластичним (рис. 3).
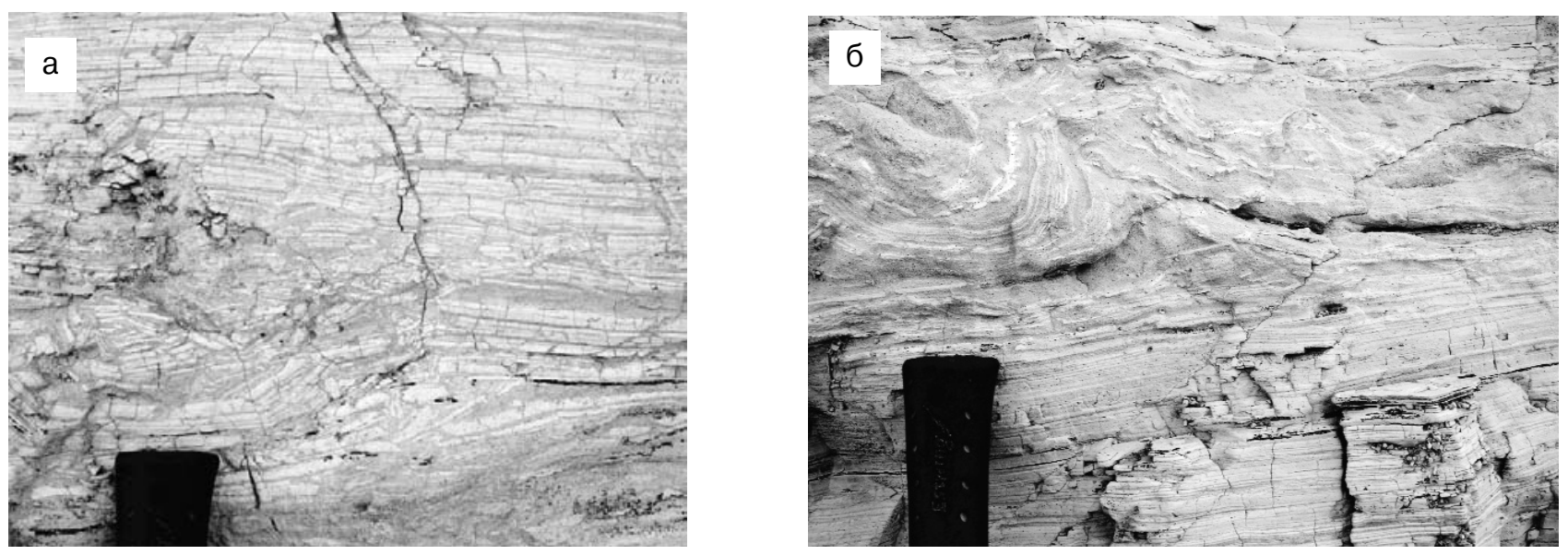

Рис. 4. Гіпс рівномірно горизонтально ламінований; представляє наявність брекчійованих прошарків (а) і гіпсу складчастого, що підстеляється гіпсом із нерівномірною ламінацією (б). Ручка молотка має ширину 3,7 см

\section{IНTЕРПРЕТАЦІЯ}

Особливості ламінованих гіпсів, такі як горизонтальне залягання ламін, яку супроводжують такі порушення як дрібні заглибини і ерозійні поверхні, хвиляста ламінація, лінзовидна ламінація, а також окремі скісноламіновані більш грубозернисті лінзи поміж дрібнозернистих відкладів, вказують на відкладення в результаті дії періодичних потоків (рис. 2-3). Ламіновані гіпси в Кудринцях дуже подібні - беручи до уваги пластичну деформацію та брекчіювання - до перевідкладених ангідрітів, котрі залягають у середній частині евапоритового басейну [14], а також до перевідкладених гіпсів, встановлених раніше на території сульфатної платформи $[17,18]$. Перешарування гіпсу рівномірно ламінованого та гіпсу з численними порушеннями, вказує на седиментаційну ґенезу цих порушень.

Гіпсові мікробіаліти, які становлять більшу частину гіпсового розрізу в Кудринцях, утворилися в результаті гіпсифікації (in situ) тонких мікробіальних матів (складених ціанобактеріями) з інкрустацією дрібними кристаликами гіпсу, ймовірно у постійно мокрих, частково виступаючих із води і періодично затоплюваних частинах мілководдя типу majanna [6]. Диференціація рельєфу в цьому середовищі була мізерна [6]. Зате ламіновані гіпси, які представляють інший етап розвитку басейну [2], могли утворюватися в інших середовищах, наприклад, в соляних або ж у слабо солонуватих котловинах (пенах salt and brackish pans), в яких не могли кристалізуватися селеніти [5]. Ламіни гіпсу утворилися швидше в результаті осадження з хмари завислих частинок, ніж з мутних потоків зависі малої густини, а кожна ламіна може представляти однин пласт затоплений стічними водами, які вимивали гіпсовий детрит із піднятих над рівнем води рівнин [9]. Слід зазначити, що перевідкладення досить часто спостерігається у сучасних евапоритових середовищах, (див., наприклад, [10, 12]). У випадку сульфатних баденських відкладів Передкарпатського прогину встановлено, що окрім домінуючого джерела, яким були дещо раніше осаджені евапорити, переробці підлягали також значно старші відклади - в кремнистоуламкових перешаровуваннях в баденських ангідритах ПдС Польщі встановлені у вторинному заляганні ранньо- і середньоміоценові форамініфери [19], а недавно Д. Перит зі співавторами, підготовлена до друку) встановили присутність перевідкладеної міоценової мікрофауни в кремнистоуламкових відкладах, що фаціально заміщають гіпси в Анадолах. 
Сумісне знаходження ламінованих гіпсів і деформаційних структур - пластичних і брекчійованих (in situ) - інтерпретуються як спровоковані землетрусами (див. [7, 14, 18]). Відсутність деформації у підстилаючих пачках ламінованих гіпсів суперечить уявленням про їх походження при зсувах (наприкл. типу debris flow), а одночасно геологічні дані виключають можливість постседиментаційної генези. Хоча пластичні деформації вказують на те, що частина перероблених осадів була неконсолідована, то присутність гіпсових брекчій утворених in situ вказує, на те, що принаймні якась частина їх була злітифікована в момент утворення.

Наскільки в процесі відкладення автохтонних гіпсів головним фактором, що обумовлював осадження, була зміна солоності розчинів, з яких випадали гіпси, настільки в процесі седиментації алохтонних гіпсів дуже важливим був тектонічний фактор, зокрема землетруси (на які можна сподіватися, беручи до уваги тектонічно активний характер території, розташованої у форланді Карпатського орогену) могли бути тим головним механізмом, який ініціював утворення як брекчій, так розрідження осадів (liquefaction) (див. дискусію [4]); тому ламіновані гіпси району Кудринців можна охарактеризувати як сейсміти. Цей термін ввів Seilacher [21] для шарів здеформованих сейсмічними рухами. Варто зазначити, що незважаючи на значну за обсягом документацію, сейсмічних ознак у стратиграфічних розрізах, все ще недостатньо однозначних критеріїв, які дозволяють ідентифікувати седиментаційні структури викликані сейсмікою, так як деформаційні структури типу soft-sediment (м'який осад), інтерпретовані як сейсміти, можуть виникнути в результаті дії інших механізмів нагромадження [11].

\section{ДИСКУСІЯ І ВИСНОВКИ}

Ламіновані гіпси Кудринців утворилися у досить мілководному середовищі, на що вказує нерегулярна ламінація. У стратиграфічному розрізі спостерігаються поперемінне напластування ламінованих гіпсів і гіпсів зі слідами деформацій, а часом - паралельно - достатньо гомогенізованих, що вказує на розрідження або флюїдизацію напівсконсолідованих осадів. На основі літературних даних [8, 22] можна зробити висновок, що пачки гіпсів зі слідами деформації пов'язані із синхронною на час осадження сейсмічною активністю, тому що:

1) пачки гіпсів зі слідами деформацій зустрічаються між шарами гіпсів, які не зазнали горизонтальних зміщень;

2) недостатньо є характеристик пов'язаних із раптовим зростанням тиску у ламінованих гіпсах під впливом залягаючих вище осадів, а також недостатньо характерних рис для масових рухів у напрямку стоку;

3) більшість зареєстрованих деформаційних структур вказує на неповну сконсолідованість гіпсу, що виключає появу деформацій зумовлених більш пізніми механізмами;

4) існує значна подібність до структур пов'язаних із сейсмічними рухами і деформаційними структурами, створеними експериментально у м'яких осадах (soft-sediment deformation) [4].

Як згадувалося, в районі Кудринців знайдено багато доказів тому, що принаймні частина гіпсів гіпси вторинні, утворилися в результаті обводнення ангідриту (котрий утворився в результаті дегідратації гіпсу), але власне факт наявності деформованих пачок в границях зовсім недеформованих пластів суперечить можливості трактування деформацій як результату діагенетичної трансформації мінералів сульфату кальцію (гіпсу в ангідрит і навпаки).

На основі цих поглядів найбільш правдоподібним механізмом утворення деформаційних структур, які спостерігаються в гіпсах, є розрідження (liquefaction) або флюїдизація, для яких спусковим механізмом була сейсмічна активність. У такому випадку такі деформації, які були виявлені в Кудринцях, мали би спостерігатися в інших відслоненнях ламінованих гіпсів розташованих у прилеглих районах. В Устечку якість відслонень $€$ низкою, але варто зауважити, що в серії алохтонних гіпсів часто зустрічаються гіпсові брекчії [3]. Правдоподібно, що Устечко було розташоване ближче до епіцентру землетрусу, а утворення сейсмітів (що також залягають в Кудринцях) було пов'язане із системою розломів Коломийської западини. Як зауважив Турчинов [23], характерною рисою Коломийської западини є широкий розвиток фації кластичних гіпсів, які деколи складають цілі розрізи гіпсів, що є результатом їхього перевідкладення з бортів западини. У свою чергу, в Анадолах не спостерігається деформації ламінованих гіпсів, але це не насторожує, враховуючи сильну перекристалізацію гіпсів цього відслонення. 
Викликані сейсмікою деформації типу «м'яких осадів» (soft-sediment) (сейсміти) рідко відзначались у гіпсових відкладах [4], але описана ситуація в Кудринцях доповнює скупий перелік деформацій цього типу в описах викопних евапоритів.

1. Перит Т.М., Перит Д. Мікрофації, вапняний нанопланктон і ізотопна геохімія ратинського вапняку Західної України і Північної Молдови. // Геологія і геохімія горючих копалин. - 1994. - 1-2 (86-87). - С. 56-64.

2. Перит Т.М., Побережський А.В., Ясиновський М.Фації баденських гіпсів Наддністров'я. // Геологія і геохімія горючих копалин. - 1995. - 1-2 (90-91). - С. 16-27.

3. Перит Т.М., Побережський А.В., Ясиновський М, Перит Д., Петриненко О.Й., Лизун С.О., Турчинов І.І. Кореляція баденських сульфатних відкладів Наддністров'я. // Геологія і геохімія горючих копалин. - 2004. - 1/2004. - С. 56-69.

4. Bachmann G.H. \& Aref M.A.M. A seismite in Triassic gypsum deposits (Grabfeld Formation, Ladinian), southwestern Germany. // Sediment. Geol. - 2005. - V. 180. - P. 75-89.

5. Babel M. Selenite-gypsum microbialite facies and sedimentary evolution of the Badenian evaporite basin of the northern Carpathian Foredeep. // Acta Geol. Pol. 2005. - V. 55. - P. 187-210.

6. Babel M. Depositional environments of a salina-type evaporite basin recorded in the Badenian gypsum facies in the northern Carpathian Foredeep. // Geol. Soc. Spec. Publ. - 2007. - V. 285. - P. 107-142.

7. Cendon D.I., Peryt T.M., Ayora C., Pueyo J.J. \& Taberner C. The importance of recycling processes in the Middle Miocene Badenian evaporite basin (Carpathian foredeep): palaeoenvironmental implications. // Palaeogeogr., Palaeoclimatol., Palaeoecol. - 2004. - V. 212. - P. 141-158.

8. Jones A.P. \& Omoto K. Towards establishing criteria for identifying trigger mechanisms for soft-sediment deformation: a case study of Late Pleistocene lacustrine sand clays, Onikobe and Nakaymadaira basins, northeastern Japan. // Sedimentology. - 2000. - V. 47. - P. 1211-1226.

9. Kasprzyk A. Sedimentary evolution of Badenian (Middle Miocene) gypsum deposits in the northern Carpathian Foredeep. // Geol. Quart. - 1999. - V. 43. - P. 449-465.

10. Logan B.W. The MacLeod evaporite basin, Western Australia. // AAPG Mem. - 1987. - V. 44. - P. 1-140.

11. Moretti M. Soft-sediment deformation structures interpreted as seismites in middle-late Pleistocene aeolian deposits (Apulia foreland, southern Italy). // Sediment. Geol. - 2000. - V. 135. - P. 167-179.
12. Orti Cabo F., Pueyo Mur J.J., Geisler-Cussey D. \& Dulau $N$. Evaporitic sedimentation in the coastal salinas of Santa Pola (Alicante, Spain). // Rev. Invest. Geol. 1984. - V. 38/39. - P. 169-220.

13. Peryt T.M. Sedimentology of Badenian (middle Miocene) gypsum in eastern Galicia, Podolia and Bukovina (West Ukraine). // Sedimentology. - 1996. - V. 43. P. 571-588.

14. Peryt T.M. Resedimentation of basin centre sulphate deposits: Middle Miocene Badenian of Carpathian Foredeep, southern Poland. // Sediment. Geol. - 2000. V. 134. - P. 331-342.

15. Peryt T.M. Gypsum facies transitions in basin-marginal evaporites: middle Miocene (Badenian) of West Ukraine. // Sedimentology. - 2001. - V. 48. - P. 1103-1119.

16. Peryt T.M. The beginning, development and termination of the Middle Miocene Badenian salinity crisis in Central Paratethys. // Sediment. Geol. - 2006. - V. 188-189. - P. 379-396.

17. Peryt T.M. \& Jasionowski M. In situ formed and redeposited gypsum breccias in the Middle Miocene Badenian of southern Poland. // Sediment. Geol. 1994. - V. 94. - P. 153-163.

18. Peryt T.M. \& Kasprzyk A. Earthquake?induced resedimentation in the Badenian (middle Miocene) gypsum of southern Poland. // Sedimentology. - 1992. - V. 39. P. 235-249.

19. Peryt T.M., Peryt D., Szaran J., Halas S. \& Jasionowski M. O poziomie anhydrytowym badenu w otworze wiertniczym Ryszkowa Wola 7 k. Jaroslawia (SE Polska). // Biul. Panstw. Inst. Geol.. - 1998. - V. 379. - P. 61-78.

20. Petrichenko O.I., Peryt T.M. \& Poberegsky A.V. Pecularities of gypsum sedimentation in the Middle Miocene Badenian evaporite basin of Carpathian Foredeep. // Slovak Geol. Mag. - 1997. - V. 3. - P. 91-104.

21. Seilacher $A$. Fault-graded beds interpreted as seismites. // Sedimentology. - 1969. - V. 13. - P. 155-159.

22. Simms J.D. Determining earthquake recurrence intervals from deformational structures in young lacustrine sediments. // Tectonophysics. - 1975. - V. 29. - P. 144-152.

23. Turchinov I.I. Sedimentation of the Miocene deposits in the Kolomiya Graben (the Carpathian Foredeep). // Biul. Panstw. Inst. Geol. - 1999. - v. 387. - P. 190-191.

\footnotetext{
1 Polish Geological Institute, Warsow, Poland

1 Польский Геологический Институт, Варшава, Польща

2 Institute of Paleobiology, PAS, Warsow, Poland

2 Институт Палеобиологии ПАН, Варшава, Польща

${ }^{3}$ Institute of Geology and Geochemistry of Combustible Minerals NAS Ukrain, Lviv, Ukrain

${ }^{3}$ Институт геологии и геохимии горючих ископаемых НАН Украины, Львов, Украина
} 